\title{
RESEARCH OF HONEY CONSUMERS' BEHAVIOR IN PROVINCE OF VOJVODINA ${ }^{12}$
}

\author{
Maja Ćirić3, Svetlana Ignjatijević, ${ }^{4}$, Drago Cvijanović ${ }^{5}$
}

\begin{abstract}
Summary
The region of Vojvodina is considered to be very favorable for honey production, whereby the area of Fruska Gora is primarily considered as the most bountiful. However, one of the key problems that honey producers encounter is the lack of understanding of consumer behavior and therefore inability to create appropriate marketing strategies and programs. Therefore, the aim of this paper is to provide assistance to honey producers in Vojvodina, to lime honey producers from Fruska Gora with protected geographical origin in particular, to identify the motives, attitudes and buying habits of consumers of honey in Vojvodina. The conclusion is carried to summarize the obtained results about what type of honey consumers in Vojvodina buy, why, where, when, how often and what are their attitudes toward the introduction of a new brand of honey. Moreover, it presents the basic guidelines to honey producers for the improvement of marketing strategies and marketing programs.
\end{abstract}

Key words: consumer behavior, motives, purchasing habits, attitudes, Fruska Gora's lime honey

JEL: Q13, M21, M31.

1 The paper was created within the project „Lime Trees \& Honey Bees for Sustainable Development of the Danube Microregion" No: 6526-00/2011/Grant 64, the project is funded by the European Union and the Austrian Development Agency

2 Paper is a part of research within the project no. III 46006 - Sustainable agriculture and rural development in the function of accomplishing strategic objectives of the Republic of Serbia in the Danube region, financed by the Ministry of Education, Science and Technological Development of the Republic of Serbia. Project period: 2011-2015

3 Maja Ćirić, Ph.D., Associate professor, Faculty of Economics and Engineering Management in Novi Sad, Cvećarska Sreet no. 2, 21000 Novi Sad, Phone: +38121 400 484, E-mail: majaciric79@yahoo.com

4 Svetlana Ignjatijević, Ph.D., Assistant Professor, Faculty of Economics and Engineering Management in Novi Sad, Cvećarska Sreet no. 2, 21000 Novi Sad, E-mail: svetlana.ignjatijevic@gmail.com

5 Drago Cvijanović PhD, Full Professor FUnivesity of Kragujevac, Faculty of Hotel Management and Tourism, Vrnjci Spa, Serbia, Phone: +381 63295 111, E-mail: dvcmmv@gmail.com

EP 2015 (62) 3 (627-644) 


\section{Introduction}

Honey represents the most famous primary product of beekeeping practices, which is most commonly consumed by consumers in its, so-called, primary condition, ie. as it is taken from bees. Additionally, honey can be used as an additive in the fructification of another product, or can be processed by creating so-called secondary product, that due to the quality and extraordinary characteristics of honey on human health has a high nutritional value (Bekić et al., 2013). Honey is a unique food that contains all the necessary elements for the growth and development of organisms (amino acids, carbohydrates, vitamins, organic acids, minerals, pollen, essential oils, proteins, enzymes, etc.). The quality of honey depends on the geographical origin and presence of plant species on the site (DugalićVrndic et al., 2011). It is due to the fact that the quality and properties of honey depend on the geographical origin, a study on the protection of geographical origin of Fruska Gora's lime honey is made and through the Lime Trees \& Honey Bees for Sustainable Development of the Danube Microregionproject, users of protected geographical origin label are identified. In relation to lime honey produced in other geographical areas, Fruska Gora's lime honey is characterized as highly monofloral, i.e. it contains a very high proportion of lime nectar which is caused by the characteristics of the geographical area and production process. Allotment of lime nectar in Fruska Gora's lime honey is located above the upper limit of the share of lime nectar in honey produced in other geographic areas. High monofloral characteristics of Fruska Gora's lime honey result in its specific sensory, melissopalynological and physical-chemical properties. (Elaborat o zaštiti oznake geografskog porekla za proizvod Fruškogorski lipov med, 2011).

The most suitable areas for the production of honey in Serbia are Sumadija and Zlatibor, while in Vojvodina it is the area of Fruska Gora. Between 2001 and 2013, according to the results obtained within the project Lime Trees \& Honey Bees for Sustainable Development of the Danube Microregion, the average production of honey in Serbia amounted to 4173 tons of which $11.24 \%$ was produced in Vojvodina. The average number of beehives in the analyzed period is 305.46 , of which approximately $16.43 \%$ are in Vojvodina. The yield of honey amounted to averaged $12.67 \mathrm{~kg}$ per hive, while in Vojvodina that amount was $11.45 \mathrm{~kg}$.

(Ignjatijević et al., 2014a) investigated the comparative advantage of Serbian exports and concluded that, in the past, Serbia had achieved a positive comparative advantage in exports of processed food sector and they rightly believe that technological and organizational modernization of Serbia can improve the current level of cooperation.(Ignjatijević et al., 2015) suggest that "companies must continually work on the sustainable development of trade by applying new technologies in management". In the period from 2004 to 2013 the average value of exported honey from Serbia amounted to 4.79 millions of dollars $\$$, and imports 62.4 thousands of dollars. The analysis of exported quantities of honey indicates a significant increase at the rate of $61.74 \%$ per annum. Exports' price has increased significantly and in the last year of export it amounted to $4.42 \$$, which is higher than the average for the ten-year period (\$3.56). The conducted analysis of the value of exports and imports of honey in Serbia indicates the negligible value of imports of honey. The demand 
for honey in the domestic market is met by domestic production, in so that the demand for imports of honey is not significant. On the other hand an expansion in exports indicates the existence of an increase in demand on the international market. This fact precisely points out the need to invest in increasing production and competitiveness of honey on both domestic and international market, in order to utilize the comparative advantage of Serbia for the export of honey and to increase the participation of Serbia in the placement of honey in the international market. But before entering the international food market it is of ultimate importance to research the consumers' requirements and desires both in quality and quantity (Ćirić, Prodanović, 2013). Besides, there is a clear need to continue with structural reforms, in order to promote export structure (Ignjatijević et al., 2014b).

The problems that producers of honey in Serbia and Vojvodina encounter in an effort to increase the production and placement of their products, both domestically and, especially, on foreign market, are numerous. One of the key problems is certainly the nonpossession of adequate knowledge of marketing, lack of understanding of the needs, desires, motives and habits of consumers and therefore the inability to create a proper marketing strategy and marketing program, which would enable them to increase market share both in domestic and international markets.

Considering the above, this paper tries to present guidelines to honey producers in Vojvodina, with special reference to the manufacturers of Fruska Gora's lime honey, which segment of the target market to focus on, what are the characteristics of consumers in this segment, which marketing strategy and marketing program to apply in order to achieve a greater market share and higher profits from the sale of their products.

\section{The importance of consumer behavior research}

Consumer behavior is a dynamic interaction of affect and thinking, behavior and the environment by means of which human beings manage the aspects of exchange in their life (Peter, Olson, 2005).The essence of successful marketing is precisely the knowledge of consumer behavior in order to create an appropriate marketing strategy and marketing mix, and to adequately meet the needs and desires of consumers. Consumer behavior is manifested in selecting, purchasing, consumption and use of products and services on the market, as well as their availability, including the final decision on the retention or rejection of a product or service. Consumers display different behavior regarding the purchase of goods and services, which is correlated with the personality characteristics, product characteristics and particularity of a specific situation. Consumer behavior in the market is influenced by many different factors that can be divided into external (outside) and internal (psychological). The external factors include demographic, economic, geographic and sociological factors, while internal factors consist of personality characteristics, its features and mental states. Although manifested individually, they are strongly influenced by external factors and affect the formation of attitudes, opinions, teachings and motives of consumers (Novaković Rajčić, 2005). Cognitive, affective and behavioral component of the attitude are intercorrelated and very important for consumer behavior and its consumption intentions (Ćirić, Ignjatijević, 2014). 
The study of consumer behavior takes interest in ways how the consumers actually use the products and services they buy, how many different brands of products they use, how often and where they buy them and above all, why they buy and use them? Contextually, consumer behavior includes what people buy, why they buy, how and where they buy, when and how often they buy products and services (Maričić, 2008).

Without knowledge of consumer behavior it is impossible to successfully plan the marketing activities of the company. Marketing managers are constantly in a position to analyze what motivates potential customers and why they exhibit certain preferences in the process of purchasing products and services on the market (Milisavljević et al., 2005). The theory and results of research of consumer behavior most often represent the basis for the laws that concern the market. The study of consumer behavior has an overriding public interest in terms of society as a whole (Ćirić et al., 2014).

In order to successfully create marketing strategies and programs, it is necessary to carry out consumer research in order to properly perform the profiling of consumers. Profiling of consumers is a type of procedure that describes the specifics of the consumers in the target market segment. It presents a description of the relevant details of the average buyer of a particular product or service. Profile of consumers in a particular market segment has a significant impact on demand for products and services from the company. Although consumers behave differently while purchasing goods and services in a variety of situations in the market, it is possible, using consistency in behavior in the consumption of consumers, to classify them in accordance to some general (common) characteristics (Maričić, 2008).

\section{Results of researches of honey consumers' behavior that have already been done in different countries}

There have been many studies done on honey consumption by American researchers. To get a better understanding of how consumers perceive honey, as well as how they use it, the National Honey Board (2013) conducted a usage and attitude survey. A total of 501 households, which consisted of men and women between the ages of 21 and 74 , were interviewed. The key results they came up with were: From 2012 to 2013, there was an increase from 54 percent to 70 percent in consumers reporting that they had purchased honey in the past year. Among moms, honey purchases had increased from 61 percent to 75 percent in the past year. Honey continues to be used predominantly for food-related purposes, including tea (55\%), as an ingredient in a recipe (51\%), and on toast/biscuits/muffins/cornbread (46\%). Over half of consumers are likely to use honey for non-food purposes. Among nonfood purposes, consumers are most likely to use honey as a cough suppressant. One in five moms reported using honey as a cough suppressant/throat soother (19\%).

Batt and Liu (2012) analyzed consumer behavior in Western Australia and came to the conclusion that honey is mostly consumed as a spread or as a sweetener on breakfast cereals and porridge. A very important part of their research concerns the comparison between the consumption behavior of Anglo-Saxon and Asian consumers. They have 
concluded that Anglo-Saxons attach more importance to the country of origin, while Asian consumers attach more importance to value and brand recognition - reputation, color and health benefits.

In their research, Murphy et al. (2000) came to the conclusion that, to Irish consumers the most important is the price and the texture of honey and then packaging, scale of production (small producers' vs. massively produced honey) and color. Irish consumers of honey were found to be price-conscious, deriving higher utility from lower priced versions of the product, while this sensitivity is also reflected on consumers' preference for larger packaging. Additionally, a thick texture had a higher utility than a runny texture. Smallscale production had a higher utility than mass production; this was also the case with dark golden color in comparison with light golden color.

When it comes to research regarding the consumption of honey and consumer behavior in purchasing and consuming of honey in Eastern Europe, researches done to date are very scarce (Arvanitoyannis, Krystallis, 2006). By exploring the literature, we have found relevant research for comparison with our country, due to similarities in geographic factors and cultures' influences, and those are researches done in Romania and Hungary which have been crucial to us for comparison with the results of the research that we have conducted.

In the eastern part of Hungary, research has been done regarding the buying habits of honey consumers. On a sample of 902 respondents it has been determined that many different types of honey are produced in Hungary, but that people do not know much about them and that they consume only a few of them. The most commonly used types of honey are traditional acacia honey and flower honey. The respondents were classified according to gender, age, qualifications and income. It was found that the most important criteria in all groups of consumers when it comes to buying honey were: quality, price, type of honey and quality of packaging. Also, it was found that older people take into account the following: price, manufacturer's name and size of the package. The highest number of consumers purchases honey just a few times a year, or a month and mostly in hypermarkets or directly from the manufacturer. Taking into account the results of the research, authors have come to the conclusion that more targeted marketing is crucial in emphasizing honey as a healthy product in order to increase consumption per capita in Hungary (Vanyi et al., 2011).

According to research done in Bucharest, Romania in 2003 with a focus on young, educated urban population, the following data regarding the consumption of honey, motives and consumer purchasing habits was discerned. More than $70 \%$ of the sample consumers bought at least $500 \mathrm{~g}$ of honey within a period of three months. The type of honey that was predominantly favored is acacia honey followed by lime honey. Purchasing honey was most often done directly from the manufacturer or at green markets, while purchases from smaller shops and supermarkets were performed only occasionally. The main motives for the purchase of honey are: medical benefits of honey consumption; dietary quality of honey; ethical character of honey; and suitability of honey with food consumption lifestyle. According to the motives for purchasing, consumers of honey in Romania are classified into three clusters: the first, 'common honey consumers', who use honey as a staple product 
in their diet; the second, 'younger consumers indifferent towards honey'; and the third segment, 'enthusiastic honey consumers' who value the therapeutic properties of honey and are more willing to pay premium prices for its organic counterpart. For the first segment of consumers the price of honey is most important, while the third segment of the consumer finds the quality of honey as crucial in the decision to purchase it. In addition, research has identified that the main elements upon which consumers evaluate the quality of honey are color, taste, aroma, thickness, while very little attention is given to the label, warranties, brand name and country-of-origin sign. (Arvanitoyannis, Krystallis, 2006). In Romania, quality cues are defined by search attributes of the bulk product, rather than credence attributes. Marketers targeting this market should be aware of this skepticism towards label information, which necessitates more communication effort to built consumer trust in brands (Athanasios et al., 2006).

During recent studies done in North-West Romania, authors Pocol and Bolboacă (2013) came up with the following findings. Although the frequency of consumption was quite high, the quantity consumed per capita was low ( $3 \mathrm{~kg} / \mathrm{year}$ on average). The most popular types of honey were acacia honey, polyfloral honey and lime honey. Respondents preferred to buy honey from local producers, and had more confidence in domestic honey than in imported honey. Honey was perceived to be a delicious product, delightful to consume and was considered beneficial for health by most of the respondents. A number of factors (education, occupation and age) significantly influenced the perception that the respondent had of the value of honey.

\section{Research method}

The purpose of this paper is to study the behavior of consumers of honey in Vojvodina, ie. determining their buying habits, motives and attitudes towards the introduction of a new brand of honey; Fruska Gora's lime honey. In addition, the paper establishes the basic demographic, economic, sociological and geographical characteristics of the test sample of consumers in Vojvodina.

The aim is to, with reference to the analysis of buying habits, motives and attitudes of consumers and their connection with the established demographic, economic, sociological and geographical characteristics of the consumers, create consumer profile which honey beekeepers of Fruska Gora's lime honey should focus on. By understanding consumer profile, honey beekeepers can be provided with basic guidance in the creation of appropriate marketing strategies and marketing programs.

Quantitative research has been applied to the research of consumer behavior, in order to carry out statistical analysis and to generalize the obtained results onto broader population. The applied method was surveying, and the instrument through which the survey was conducted was a questionnaire that was not standardized, but it had been purposely created for this survey. The research was conducted on the territory of Vojvodina, in 25 towns and villages (towns: Novi Sad, Kikinda, Vrbas, Apatin, Vrsac, Sombor, Subotica, SremskaMitrovica, Ruma, Zrenjanin, Indjija, Kula; villages: Kisac, 
Backi Petrovac, Vrdnik, Idjos, Rumenka Gajdobra, Cerevic, Sivac, Budisava, Krcedin, Backi Jarak, Temerin, Kac). The time interval in which the survey was carried out was the period between July and August 2014.

The research sample represents 500 randomly selected respondents. Random selection method was used to select a representative sample.

The data was analyzed by use of SPSS for Windows 17.0. As the methods the descriptive statistics, frequencies and percentages were used.

\section{Results and discussion}

In the literature review, we mentioned that consumer behavior depends on the demographic, economic, sociological and geographical characteristics, as well as their internal psychological factors. Therefore, we started the research with the analysis of external influences on consumers, i.e. we examined the demographic, economic, sociological and geographical characteristics of consumers, and then we analyzed a part of internal factors, i.e. their motives, attitudes, as well as demonstrated purchasing habits. Based on the obtained information we have created consumer profile on which manufacturers of Fruska Gora's lime honey in Vojvodina should focus on.

Table 1. Demographic, economic, sociological and geographical characteristics of the test sample of consumers in Vojvodina

\begin{tabular}{|c|c|c|c|c|}
\hline \multirow{2}{*}{1.} & \multirow{2}{*}{ Gender } & Male & 194 & $39 \%$ \\
\hline & & Female & 306 & $61 \%$ \\
\hline \multirow{6}{*}{2.} & \multirow{6}{*}{ Age } & Up to age 20 & 9 & $2 \%$ \\
\hline & & $20-30$ & 175 & $35 \%$ \\
\hline & & $30-40$ & 166 & $33 \%$ \\
\hline & & \begin{tabular}{|l|}
$40-50$ \\
\end{tabular} & 84 & $17 \%$ \\
\hline & & $50-60$ & 39 & $8 \%$ \\
\hline & & Over 60 & 27 & $5 \%$ \\
\hline \multirow{5}{*}{3.} & \multirow{5}{*}{ Level of education } & Elementary school & 4 & $1 \%$ \\
\hline & & \begin{tabular}{|l} 
High school \\
\end{tabular} & 117 & $23 \%$ \\
\hline & & Higher education & 43 & $9 \%$ \\
\hline & & University degree & 147 & $29 \%$ \\
\hline & & Other (Master, PhD) & 189 & $38 \%$ \\
\hline \multirow{6}{*}{4.} & \multirow{6}{*}{$\begin{array}{l}\text { Number of household } \\
\text { members }\end{array}$} & 1 & 38 & $8 \%$ \\
\hline & & 2 & 105 & $21 \%$ \\
\hline & & 3 & 131 & $26 \%$ \\
\hline & & 4 & 162 & $32 \%$ \\
\hline & & 5 & 47 & $9 \%$ \\
\hline & & More than 5 & 17 & $3 \%$ \\
\hline \multirow{4}{*}{5.} & \multirow{4}{*}{$\begin{array}{l}\text { Do you have children } \\
\text { or parents who live } \\
\text { together with you in the } \\
\text { household? }\end{array}$} & Have children & 183 & $37 \%$ \\
\hline & & Have parents & 160 & $32 \%$ \\
\hline & & Have children and parents & 36 & $7 \%$ \\
\hline & & No children and no parents & 121 & $24 \%$ \\
\hline
\end{tabular}




\begin{tabular}{|c|c|c|c|c|}
\hline \multirow{6}{*}{6.} & \multirow{6}{*}{$\begin{array}{l}\text { Total average income of } \\
\text { your household is: }\end{array}$} & Up to 20000 & 10 & $2 \%$ \\
\hline & & $20000-40000$ & 50 & $10 \%$ \\
\hline & & $40000-60000$ & 100 & $20 \%$ \\
\hline & & $60000-80000$ & 97 & $19 \%$ \\
\hline & & Over 80000 & 185 & $37 \%$ \\
\hline & & Don't know & 49 & $10 \%$ \\
\hline \multirow{3}{*}{7.} & \multirow{3}{*}{ Do you eat healthy? } & Yes & 194 & $39 \%$ \\
\hline & & No & 27 & $5 \%$ \\
\hline & & Partially & 279 & $56 \%$ \\
\hline \multirow{3}{*}{8.} & \multirow{3}{*}{$\begin{array}{l}\text { Do you exercise or } \\
\text { engage in some physical } \\
\text { activity? }\end{array}$} & Yes, regularly & 142 & $28 \%$ \\
\hline & & Yes, occasionally & 268 & $54 \%$ \\
\hline & & $\mathrm{Ne}$ & 90 & $18 \%$ \\
\hline \multirow{3}{*}{9.} & \multirow{3}{*}{$\begin{array}{l}\text { Do you consume honey } \\
\text { everyday because you } \\
\text { like it or do you use it } \\
\text { only when you are sick? }\end{array}$} & I consume it because I like it & 255 & $51 \%$ \\
\hline & & I consume it because it is healthy & 177 & $35 \%$ \\
\hline & & $\begin{array}{l}\text { I do not like very much, I only consume it } \\
\text { when I am sick }\end{array}$ & 68 & $14 \%$ \\
\hline \multirow{6}{*}{10.} & \multirow{6}{*}{$\begin{array}{l}\text { Do other people's } \\
\text { opinions affect your } \\
\text { decision to buy honey? }\end{array}$} & Friends & 91 & $18 \%$ \\
\hline & & Family & 169 & $34 \%$ \\
\hline & & Doctors & 38 & $8 \%$ \\
\hline & & Media & 21 & $4 \%$ \\
\hline & & Other & 19 & $4 \%$ \\
\hline & & I make my own decision & 300 & $60 \%$ \\
\hline \multirow{2}{*}{11.} & \multirow{2}{*}{ Place where you live } & City & 423 & $84,6 \%$ \\
\hline & & Village & 77 & $15,4 \%$ \\
\hline
\end{tabular}

Source: Created by the authors based on authors 'survey within the project „, Lime Trees \&Honey Bees for Sustainable Development of the Danube Microregion” No: 6526-00/2011/Grant 64, the project is funded by the European Union and the Austrian Development Agency

In the sample of test population men and women are equally represented, with a slightly larger proportion of women of $61 \%$. The most represented population is 20 40 years of age. Up to 20 years population is the least represented one with only $2 \%$, while the population over 50 years is merely represented by $13 \%$, which we have taken into account when defining the age profile of consumers because, according to the literature review, population of over 50 years of age is a significant consumer of honey, and thus should not be ignored. Population with university education is dominant, but there is a relevant number of respondents with high school education, which is also important for defining consumer profile. Families with two, three and four members of domestic household are equally represented. The majority of the tested population is either those who live with children $37 \%$, or those who live with their parents in the household 32\%. Given that the population sample is dominated by those with higher education, it is not surprising that the average household income is higher than the average salary in Serbia. It should therefore be noted that, in defining the product price, this group of consumers has a lower flexibility when it comes to increasing the prices compared to consumers with incomes below the average. Answers to the questions whether the respondents eat healthy food and whether they 
exercise or engage in some physical activity, indicate that a higher percentage of respondents leads a healthy lifestyle. The results show that an individual's decision to purchase honey is mostly affected by two reference groups; families $34 \%$ and friends $18 \%$. While the majority of respondents make independent decisions, which can be related to the fact that due to the long-term purchasing of products from the same manufacturer there is no need for information in the decision-making process, information gathering phases and assessment of alternatives are altogether skipped and the decision to purchase is made routinely by habit. In the structure of the interviewed population both respondents from cities and from villages are present, with a majority share $(84.6 \%)$ of respondents that live in cities.

After identifying the main external characteristics of the sample of consumers we investigated their purchasing habits and motives of behavior. In that way, we got the answers to the questions; what people buy, why they buy, where they buy, when and how often they buy honey.

Table 2. Purchasing habits and motives of honey consumers in Vojvodina

\begin{tabular}{|c|c|c|c|c|}
\hline \multirow[t]{2}{*}{1.} & \multirow{2}{*}{$\begin{array}{l}\text { Do you consume } \\
\text { honey? }\end{array}$} & Yes & 472 & $94 \%$ \\
\hline & & No & 28 & $6 \%$ \\
\hline \multirow[t]{4}{*}{2.} & \multirow{4}{*}{$\begin{array}{l}\text { How often do you } \\
\text { buy honey? }\end{array}$} & Once a month & 147 & $29 \%$ \\
\hline & & Once in 3 months & 209 & $42 \%$ \\
\hline & & Once in 6 months & 116 & $23 \%$ \\
\hline & & I don't buy honey & 28 & $6 \%$ \\
\hline \multirow[t]{4}{*}{3.} & \multirow{4}{*}{$\begin{array}{l}\text { What package size } \\
\text { of honey do you } \\
\text { buy? }\end{array}$} & $250 \mathrm{~g}$ & 39 & $8 \%$ \\
\hline & & $500 \mathrm{~g}$ & 157 & $31 \%$ \\
\hline & & $1 \mathrm{~kg}$ & 276 & $55 \%$ \\
\hline & & I don't buy honey & 28 & $6 \%$ \\
\hline \multirow[t]{9}{*}{4.} & \multirow{9}{*}{$\begin{array}{l}\text { What kind of } \\
\text { honey do you buy? }\end{array}$} & Acacia honey & 116 & $23 \%$ \\
\hline & & Polyfloral honey & 95 & $20 \%$ \\
\hline & & Lime honey & 24 & $5 \%$ \\
\hline & & Forest honey & 17 & $4 \%$ \\
\hline & & Acacia, lime and polyfloral honey & 49 & $10 \%$ \\
\hline & & Acacia and lime honey & 21 & $4.2 \%$ \\
\hline & & Acacia and polyfloral honey & 58 & $12 \%$ \\
\hline & & Acacia, lime and forest honey & 11 & $3 \%$ \\
\hline & & $\begin{array}{l}\text { Don't buy honey, buy other kinds of honey and } \\
\text { other imprecise answers }\end{array}$ & 109 & $18,8 \%$ \\
\hline
\end{tabular}




\begin{tabular}{|c|c|c|c|c|}
\hline \multirow[t]{4}{*}{5.} & \multirow{4}{*}{$\begin{array}{l}\text { Do you consume } \\
\text { honey everyday } \\
\text { because you like } \\
\text { it or do you use it } \\
\text { only when you are } \\
\text { sick? }\end{array}$} & I consume it because I like it & 255 & $51 \%$ \\
\hline & & I consume it because it is healthy & 177 & $35 \%$ \\
\hline & & $\begin{array}{l}\text { I do not like very much, I only consume it when } \\
\text { I am sick }\end{array}$ & 40 & $8 \%$ \\
\hline & & I do not consume honey & 28 & $6 \%$ \\
\hline \multirow[t]{6}{*}{6.} & \multirow{6}{*}{$\begin{array}{l}\text { Where do you } \\
\text { most often buy } \\
\text { honey? }\end{array}$} & Directly from manufacturer (beekeeper) & 203 & $40,6 \%$ \\
\hline & & At the green market & 158 & $31,6 \%$ \\
\hline & & In grocery shop & 82 & $16,4 \%$ \\
\hline & & At the honey festival & 17 & $3,4 \%$ \\
\hline & & In monastery & 4 & $0,8 \%$ \\
\hline & & I do not buy honey and other imprecise answers & 36 & $7,2 \%$ \\
\hline \multirow[t]{4}{*}{7.} & \multirow{4}{*}{$\begin{array}{l}\text { Do you consume } \\
\text { honey throughout } \\
\text { the year or do } \\
\text { you increase } \\
\text { consumption } \\
\text { during a specific } \\
\text { time of the year (or } \\
\text { season) }\end{array}$} & Throughout the year & 334 & $66,8 \%$ \\
\hline & & In winter & 91 & $18,2 \%$ \\
\hline & & In spring & 7 & $1,4 \%$ \\
\hline & & They do not buy honey and other imprecise answers & 68 & $13,6 \%$ \\
\hline
\end{tabular}

Source: Created by the authors based on authors' survey within the project „Lime Trees \& Honey Bees for Sustainable Development of the Danube Microregion" No: 6526-00/2011/ Grant 64, the project is funded by the European Union and the Austrian Development Agency

The first question, from which we started the study, was to measure the percentage of respondents who consume honey in their diet. The obtained results indicated that 472 respondents (94\%) use honey in their diet, while 28 of them $(6 \%)$ do not consume honey. The answer to the above question resulted in a conclusion that honey is a product that falls into the category of consumer goods which is present in the diet of, as much as, $94 \%$ of the test population on the territory of Vojvodina. However, this information does not yet give us an accurate picture about to what extent and how often honey is consumed; we will learn that through the answers to second and third question.

The respondents' answers to the second question show us the habits of consumers regarding the frequency of honey purchases. From the above, we observe that, the out of total number of respondents, $29 \%$ of them purchase honey once per month and $42 \%$ of them do so once in three months. Therefore, $71 \%$ of respondents fall in the category of consumers who often buy honey, whereas $23 \%$ of respondents buy honey only once in six months, which means that their consumption of honey is pretty meager. This information is important to connect with the amount of honey to be purchased in order to define a segment of consumers who are the biggest consumers of honey, i.e. those who have a habit of consuming honey to a greater extent. 
The answers given to the third question, which refers to the habits of consumers related to the purchase of certain size of packaging, indicate that the largest consumer preference is to buy packs of $1 \mathrm{~kg}, 55 \%$ of respondents, whereas $31 \%$ of respondents buy packs of $500 \mathrm{~g}$, while only $8 \%$ of respondents buy packs of $250 \mathrm{~g}$.

If we connect the frequency of purchases of honey with the amount of honey consumed by respondents, we get the information that $15.8 \%$ of respondents buy honey in packs of $1 \mathrm{~kg}$ once a month, $9.6 \%$ of respondents buy honey in packs of $500 \mathrm{~g}$ once a month, $24.6 \%$ of respondents buy honey in $1 \mathrm{~kg}$ packs once in 3 months. Thus, $50 \%$ of respondents purchase honey in significant quantities from $333 \mathrm{~g}$ to $1 \mathrm{~kg}$ on average per month, while the remaining $50 \%$ of respondents either do not buy honey $(6 \%)$ or, if they buy it, quantities are extremely modest; $41,7 \mathrm{~g}$ to $250 \mathrm{~g}$ on average per month. The obtained data significantly changes the picture given by the initial research that even $94 \%$ of the test population consumes honey.

In relation to the research by Arvanitoyannis and Krystallis (2006), more than 70\% of respondents in Bucharest buy at least $500 \mathrm{~g}$ of honey every three months, which amounts to an average of $166 \mathrm{~g}$ per month, as well as in relation to the research by Pocol and Bolboacă (2013) according to which the average consumption of honey in Romania is $3 \mathrm{~kg}$ per capita annually, which amounts to an average of $250 \mathrm{~g}$ of honey per month, we can conclude that customers in Vojvodina have a much higher propensity to consumption of honey compared to consumers in Romania.

When analyzing which type of honey is purchased by respondents, by summarizing responses to the open question, we see that consumption is dominated by acacia and polyfloral honey. Lime honey is exclusively purchased by only $5 \%$ of respondents, acacia, lime and polyfloral honey are purchased by $10 \%$ of respondents, while $4.2 \%$ of respondents buy acacia and lime honey. Therefore, lime honey does not fall into the category of honey whose consumption has a dominant position in the market. Acacia and polyfloral honey are, compared to lime honey, much more represented in the consumption of the tested population in Vojvodina. If we compare this data with the research performed in Hungary, we can see that consumption of acacia honey also dominates there but, unlike Vojvodina, polyfloral honey holds a second place in Hungary's honey consumption. In Bucharest, Romania, consumption of acacia and lime honey dominates, while Northwest Romania is dominated by consumption of acacia, polyfloral and lime honey. As we can see, acacia honey is the type of honey that is characteristically dominant in consumption in Vojvodina, as well as in Hungary and Romania, while the preferences of other types of honey vary in researched areas.

The motives for the consumption of honey are, on one hand the satisfaction that taste of honey provides to $51 \%$ of the test population, but for $35 \%$ of the respondents the basic motive is concern for health, which is in accordance with their lifestyle.

The main motives for buying honey in Bucharest, Romania are: medical benefits of honey consumption; dietary quality of honey; ethical character of honey; and suitability of honey with food consumption lifestyle, wherein the dominance of a particular motive depends on the characteristics of consumers. Comparing the data 
that we received by way of research and motives which were obtained through research in Romania, we notice that the motives for the consumption of honey are essentially similar, and which one will dominate depends on the internal and external factors that influence consumer behavior.

On the basis of summarizing the responses to the open question, we get a clear picture that the majority of respondents, as many as $40.6 \%$, has a habit of purchasing honey directly from the manufacturer of honey - known beekeepers, which can be linked to the fact that, given their inability to check the quality of honey, trust in such beekeeper and long term relationship of loyalty they build together is a factor that has the greatest influence when deciding to purchase a particular honey. In addition, other factor contributing to their decision is the cost of honey, which is lower when purchased from manufacturers than it is when purchased through intermediaries. We can also deduct that a significant portion of respondents opts to purchase honey at green markets $(31.6 \%)$ and in stores of various profiles; from health food stores to large supermarkets (16.4\%). Comparing our results with the results obtained in Hungary, consumer research shows us that consumers in Vojvodina as well as consumers in Hungary are in the habit of buying honey primarily from the manufacturer directly. However, while consumers in Hungary have a more pronounced habit to buy honey in stores, in Vojvodina, as we can see, the percentage of consumers who buy honey in stores is rather small (16.4\%). Comparison with consumers in Romania displays a greater similarity, because among consumers in Romania there is also a predominance to buy honey directly from the manufacturer and then at green markets, as shown in the research conducted in 2003, as well as in 2013. With regard to the time of year when consumers buy honey, we can see that $66.8 \%$ of respondents purchase honey throughout the year. However, $18.2 \%$ of them show a greater inclination and habit to buy honey during the winter, which can be associated with more frequent colds in the winter time and the use of honey as a supplemental medicinal resource in this time of year.

Table 3. Attitudes of honey consumers in Vojvodina towards the introduction of a new brand of honey

\begin{tabular}{|c|c|c|c|c|}
\hline \multirow{4}{*}{1.} & \multirow{4}{*}{$\begin{array}{l}\text { Would you be willing to try } \\
\text { Fruska Gora's lime honey } \\
\text { with above average quality } \\
\text { and guaranteed certificate? }\end{array}$} & Yes & 416 & $83 \%$ \\
\hline & & No & 17 & $3 \%$ \\
\hline & & Maybe & 54 & $11 \%$ \\
\hline & & Do not know & 13 & $3 \%$ \\
\hline \multirow{5}{*}{2.} & \multirow{5}{*}{$\begin{array}{l}\text { What is the maximum } \\
\text { price you would be willing } \\
\text { to pay for } 1 \mathrm{~kg} \text { of Fruska } \\
\text { Gora's lime honey with } \\
\text { above average quality and } \\
\text { guaranteed certificate? }\end{array}$} & Up to 500 RSD & 6 & $1,2 \%$ \\
\hline & & \begin{tabular}{|l|} 
Between 500-800 RSD \\
\end{tabular} & 179 & $35,8 \%$ \\
\hline & & \begin{tabular}{|l|} 
Between 800-1000 RSD \\
\end{tabular} & 170 & $34 \%$ \\
\hline & & 1000 RSD & 111 & $22,2 \%$ \\
\hline & & Over 1000 RSD & 34 & $6,8 \%$ \\
\hline
\end{tabular}

Source: Created by the authors based on authors' survey within the project „Lime Trees \& Honey Bees for Sustainable Development of the Danube Microregion" No: 6526-00/2011/ Grant 64, the project is funded by the European Union and the Austrian Development Agency 
The attitude of even $83 \%$ of respondents that they would be willing to try Fruska Gora's lime honey that possesses above average quality and guaranteed certificate, operates as encouragement for producers of Fruska Gora's lime honey and indicates that regardless of the small market share of lime honey consumption, compared to other types of honey, applying appropriate marketing strategy and marketing program the market share of lime honey consumption could be significantly improved.

To obtain guidance on the price which consumers would be willing to pay for a new branded product, Fruska Gora's lime honey of high quality, we asked an open question number 2 (as shown in Table 3) and we summarized and displayed the obtained results. Based on the received results we see that $63 \%$ of respondents are willing to pay a price higher than 800 dinars per kilogram of lime honey, which has an above average quality and is certified, while $29 \%$ of them would even be willing to part with 1000 dinars or more for such a product. Add to this the information that at the moment the greatest number of respondents (52\%) pays between 500 and 700 dinars for $1 \mathrm{~kg}$ of honey. Even $35 \%$ of respondents pay less than 500 dinars per kilo, while only $13 \%$ of the population allocates over 700 din.

If we compare the data on the price of 800 dinars and the price of 500-700 dinars, which the largest number of respondents $(52 \%)$ at the time of interview are ready to part with, we find that respondents are willing to pay a roughly $30 \%$ higher price than the average market price per kilogram of lime honey that has an above average quality and is certified. Therefore, appropriate marketing strategy and marketing program that place an emphasis on the above average quality of Fruska Gora's lime honey and guarantee compliance with the standard of quality, create a possibility to achieve a significantly higher price than the one that the majority of respondents is currently paying.

Based on the research of demographic, economic, sociological and geographical characteristics of consumers in the territory of Vojvodina; their buying habits, motives and attitudes that are related to the introduction of the new brand that is Fruska Gora's lime honey, we have created a profile of consumers to which producers of Fruska Gora's lime honey should focus on.

Consumers who purchase and consume the largest amount of honey on average between $333,33 \mathrm{~g}$ to $1 \mathrm{~kg}$ on a monthly basis represent the most important market segment which the honey producers should focus on. These are consumers who said they buy $1 \mathrm{~kg}$ of honey per month, $500 \mathrm{~g}$ per month and $1 \mathrm{~kg}$ of honey in three months. This market segment accounts for $50 \%$ of the test population. The aim of manufacturers is to create preferences towards the purchase and consumption of Fruska Gora's lime honey with these consumers. These consumers have the following demographic, economic, sociological and geographical characteristics.

According to the gender structure of the consumers, both men and women are equally statistically significant.

According to the age structure of consumers that are dominant in the purchase of honey are persons in ages between 20-30, 30-40 and 40-50 years of age. Taking into account 
that the tested sample contained a small percentage of the population over the age of 50 , as well as taking into account the experience of honey producers in direct sales of honey, to whom the population over the age of 50 is a very important segment of loyal customers, neither of them should be omitted when defining the profile of the consumer.

According to the level of education, purchasing honey is dominated by those with tertiary education and higher, i.e. Masters Degree and $\mathrm{PhD}$.

According to the number of members in domestic household, three member and four member households dominate in the purchase of honey.

Honey consumers are customers themselves, along with their children and their parents to whom they purchase honey. This means that honey is bought for the whole household. Customers are, according to the above characteristics, an active population with high education, but beside them, consumers of purchased honey are their children and their parents as well.

When it comes to overall average household income, purchasing honey is dominated by households with incomes of minimum 40,000-60,000 dinars, 60,000-80,000 dinars and over 80,000 dinars.

Honey consumers are persons who, completely or partially, eat healthy food. They also exercise or engage in some physical activity regularly or occasionally. Therefore, those are such persons who have a tendency towards a healthy lifestyle.

Motives for the purchase of honey are on one hand the fact that customers prefer the taste of honey, and on the other hand the fact that honey is considered as healthy food. Accordingly, consumers who buy honey throughout the year prevail marginally, but those consumers who buy it during the winter, when the intensity of colds is greater, are also significant statistically.

Family is the only reference group that has a statistically significant effect on the respondents' decision to buy honey, while the majority of respondents make that decision independently.

Both city and rural residents have a propensity to purchase honey.

According to expressed views, such profile of consumers prefers certified, high quality honey and for that product is willing to pay about $30 \%$ higher price, which is necessary to bear in mind when defining marketing programs for producers of Fruska Gora's lime honey.

\section{Conclusion}

Through the research of buying habits and motives of consumers, we have reached the conclusion that, although as many as $94 \%$ of respondents claim to consume honey, only $50 \%$ of them consume substantial amounts of $333 \mathrm{~g}$ to $1 \mathrm{~kg}$ of honey on average per month. Types of honey that consumers prefer are acacia and polyfloral honey. The motives for the consumption of honey are on one hand the satisfaction that taste of honey provides for $51 \%$ of 
the test population, whereas for $35 \%$ of the respondents, the basic motive is concern for health, which is in accordance with their lifestyle. The largest percentage of respondents $(40.6 \%)$ purchases honey directly from manufacturers, and then at green markets (31.6), while a fairly small percentage of respondents buys honey in shops of different profile (16.4\%) which is, on one hand, related to the confidence that consumers place in the producers and quality of honey and, on the other hand, a lower price that consumers pay in direct purchase than in stores. The highest percentage of consumers purchase honey throughout the year (66.8\%), while certain seasonal nature still exists because $18.2 \%$ of them declare that they buy honey more frequently in the winter, which is related to the use of honey as a supplemental medicinal remedy during intense colds.

While researching consumer attitudes, we have come to the conclusion that the majority of consumers, as many as 83\%, are willing to try Fruska Gora's lime honey that is of above average quality and is certified, regardless of the fact that lime honey does not belong to the type of honey which consumers buy. The reason for this lies in the fact that consumers prefer a high quality of honey because it is linked to better taste and better healing properties of honey, which is in line with the motivations of consumers. For such a quality and certified honey, consumers are willing to pay even a 30\% higher price than the average market price of lime honey.

By researching the buying habits, motives and attitudes of consumers, as well as their demographic, economic, sociological and geographic features, we have defined the profile of consumers who represent the largest buyers and consumers of honey which the producers of honey in Vojvodina and especially producers of Fruska Gora's lime honey should focus on. It is about customers, men and women, who are highly educated, active workers with above average income compared to the average salary in Serbia, who purchase honey for their own consumption and the consumption of the entire households that consist of their children and parents. Moreover, it is the consumers who prefer high quality products and foster a healthy lifestyle. The marketing strategy that producers of Fruska Gora's lime honey should implement is the strategy of concentration on one market segment. The producers of Fruska Gora's lime honey need to adjust their complete marketing program to this consumer profile. Based on the characteristics of the consumer profile we have presented the basic guidelines for the marketing program that could be a guiding principle for the manufacturers of Fruska Gora's lime honey as well as for other producers of honey in Vojvodina who have products with similar characteristics.

When it comes to Fruska Gora's lime honey brand, regardless of the high quantity of producers of Fruska Gora's lime honey, the name and complete visual identity of the product should be unique. Only then can we build a uniquely recognizable brand. Moreover, given that it is intended for consumers with above average income, it should be packed in special luxury designed packages in sizes of $500 \mathrm{~g}$ and $1 \mathrm{~kg}$, which is consistent with the purchasing habits of consumers. Thanks to the properties and quality of Fruska Gora's lime honey which is, due to the geographical origin, of above average quality in relation to lime honey in other areas, it can be differentiated in the market in comparison to other types of honey and branded as exceptional honey with above average quality which is, according 
to the views expressed, very important to the studied consumers. As a basic guideline in creating price, the producers of Fruska Gora's lime honey should take into consideration customer preferences and prices that competitors in the market create for lime honey that is not from Fruska Gora or for lime honey that is not branded. According to our research, consumers are willing to pay a roughly $30 \%$ higher price than the average market price per kilogram of Fruska Gora's lime honey, which has an above average quality and is certified. With regard to customers from the territory of Vojvodina, Fruska Gora's lime honey should still be predominantly sold directly from individual producers, given the already built loyal base of customers and their purchasing habits, but it is also necessary to actively take part in selling at green markets, through all honey related events and to take particular focus on health food stores and shops of organic products. By increasing the production of honey and strengthening the potency of offer, the expansion of distribution channels can be considered. When it comes to promotion, it is necessary to make an optimal combination of media in accordance with the defined profile of consumers and available budget, and to work intensively on building a unique brand in order to make Fruska Gora's lime honey an association of above average quality and a healthy lifestyle in the minds of the consumers.

Studies of consumer behavior and creation of marketing strategies and marketing programs, based on the information obtained from research, do not necessarily mean irrevocable success in the market. However, they greatly reduce the risk of error and increase the chance that the product or service would be accepted by consumers and thus provide an adequate market share and profit to producers.

\section{Literature}

1. Arvanitoyannis, I., Krystallis, A. (2006): An empirical examination of the determinants of honey consumption in Romania, International Journal of Food Science \& Technology, vol. 41, no. 10, pp. 1164-1176.

2. Athanasios, K, Dan, P. Ioannis, A (2006): From Commodities to the Consumption of Quality Foods in Eastern European Context: An Empirical Examination of the Determinants of Consumer Behavior Towards Honey, Journal of East-West Business,vol. 12, no. 4, pp. 5-37.

3. Bekić, B., Jeločnik, M., Subić, J. (2013): Med i proizvodi od meda, Radovi sa XXVI savetovanja agronoma, veterinara, tehnologa i agroekonomista, vol. 18, no. 3-4, pp. 177-184.

4. Batt, P. J., Liu, A. (2012): Consumer behaviour towards honey products in Western Australia, British Food Journal, vol. 114, pp. 285-297.

5. Ćirić M., Počuča M., Raičević V., (2014): Level of customer orientation and customer protection in hotels in Serbia, Ekonomika poljoprivrede, vol. 61, no. 1, pp. 25-39.

6. Ćirić, M. Ignjatijević, S. (2014): Analiza komponenti stava u funkciji zaštite potrošača u Srbiji, Marketing, vol. 45, no. 3, pp. 187-200.

7. Ćirić, M., Prodanović, R. (2013): Strategija pozicioniranja organskih prehrambenih proizvoda, Ekonomija- teorija I praksa, vol. 6, no. 3, pp. 33-48. 
8. Dugalić-Vrndić, N., Kečkeš, J., Mladenović, M. (2011): The authencity of honey in relation to quality parameters, Biotechnology in Animal Husbandry, vol. 27, no. 4, pp. 1771-1778.

9. Ignjatijević, S., Matijašević, J. and Milojević, I. (2014a): Reveald comparative adventages and competitiveness of the processed food sector for the Danube countries, Custos E Agronegocio on line, vol. 10, no. 3, pp. 256-281.

10. Ignjatijević, S., Čavlin, M. I Đorđević, D. (2014b): Measurement of comparative adventages of processed food sector of Serbia in the increasing the export, Ekonomika poljoprivrede, vol. 61, no. 3, pp. 127-138.

11. Ignjatijević, S.,Milojević, I., Cvijanović, G., Jandrić, M. (2015): Balance of Comparative Advantages in Processed Food Sector of the Danube Countries, Sustainability, vol. 7, no. 6, pp. 6976-6993.

12. Maričić, B. (2008): Ponašanje potrošača, Centar za izdavačku delatnost ekonomskog fakulteta u Beogradu, Beograd.

13. Milisavljević, M., Maričić B., Gligorijević M., (2005): Osnovi Marketinga, Centar za izdavačku delatnost ekonomskog fakulteta u Beogradu, Beograd.

14. Murphy, M., Cowan, C., Henchion, M., O’Reilly, S. (2000): Irish consumer preferences for honey: a conjoint approach, British Food Journal, vol. 102, pp. 585-598.

15. Novaković Rajčić, B. (2005): Ponašanje potrošača, Evropski univerzitet, Beograd.

16. Peter, P., Olson, J. (2005): Consumer Behavior and Marketing Strategy, Irwin/ McGraw Hill, Boston.

17. Pocol, C. B., Bolboacă, S. D. (2013): Perceptions and trends related to the consumption of honey: A case study of North-West Romania, International Journal of Consumer Studies, vol. 37, no. 6, pp. 642-649.

18. Vanyi, G. A.,Csapo, Z., Karpati, L. (2011): Evaluation of Consumers' Honey Purchase Habits in Hungary, Journal of Food Products Marketing, vol. 17, no. 2/3, pp. 227-240.

19. Elaborat o zaštiti oznake geografskog porekla za proizvod Fruškogorski lipov med, Univerzitet u NovomSadu, Prirodno matematički fakultet, Novi Sad, 2011.

20. National Honey Board (2013) (available at: http://www.honey.com/honeyindustry/honey-and-bee-research/market-research/). 


\title{
ISTRAŽIVANJE PONAŠANJA POTROŠAČA MEDA U VOJVODINI
}

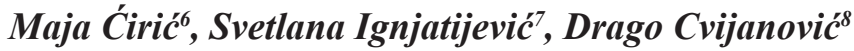

\begin{abstract}
Apstrakt
Područje Vojvodine se smatra veoma povoljnim za proizvodnju meda, pri čemu se u prvom redu ističe područje Fruške gore. Međutim, jedan od veoma važnih problema sa kojim se proizvođači meda susreću jeste u nerazumevanju ponašanja potrošača $i$ samim tim u nemogućnosti kreiranja odgovarajuće marketing strategije i programa. Stoga je cilj ovog rada da se pomogne proizvođačima meda u Vojvodini, a posebno proizvođačima Fruškogorskog lipovog meda sa zaštićenim geografskim poreklom, $u$ identifikaciji motiva, stavova $i$ kupovnih navika potrošač ameda u Vojvodini. $U$ zaključku se vrši sumiranje dobijenih rezultata o tome koju vrstu meda potrošači u Vojvodini kupuju, zašto, gde, kada, koliko često i kakvi su im stavovi prema uvođenju novog Brenda meda. Osim toga, iznose se osnovna uputstva proizvođačima meda za unapređenje marketing strategije i marketing programa.
\end{abstract}

Ključne reči: ponašanje potrošača, motivi, kupovne navike, stavovi, Fruškogorski lipov med.

6 Vanredni profesor, dr Maja Ćirić, Fakultet za ekonomiju i inženjerski menadžment u Novom Sadu, Cvećarska 2, Novi Sad, Srbija, Telefon: 021/400-484, majaciric79@yahoo.com

7 Docent, dr Svetlana Ignjatijević, Fakultet za ekonomiju i inženjerski menadžment u Novom Sadu, Cvećarska 2, Novi Sad, Srbija, Telefon: 021/400-484, svetlana.ignjatijevic@gmail.com

8 Redovni profesor, dr Drago Cvijanović, Univerzitet u Kragujevcu, Fakultet za hotelijerstvo i turizam u Vrnjačkoj Banji, Vrnjačka Banja, Srbija, Telefon: +381 63295 111, E-mail: dvcmmv@gmail.com 